1914. The fishes of New England. The salmon family, Part I. The trout or charrs. Mem. Boston Soc. Nat. Hist. 8(1): 1-103.

McPinall, J. D. 1961. A systematic study of the Salvelinus alpinus complex in North America. J. Fish. Res. Bd. Canada 18: 793-814.

Scott, W. B., and E. J. Crossman. 1964. Fishes occurring in the fresh waters of insular Newfoundland. Canada Dept. Fisheries, Ottawa, 124 p.

Stilwell, E. M., and Henry O. Stanley. 1874. Eighth report of the commissioners of fisheries for the State of Maine, $43 \mathrm{p}$.

VLADYKOV, V. D. 1954. Taxonomic characters of the eastern North America char's (Salvelinus and Cristivomer). J. Fish. Res. Bd. Canada 11: 904-932.

W. Harry Everhart Charles A. Waters ${ }^{2}$

Maine Department of Inland Fisheries and Game, and University of Maine

Orono, Maine

${ }^{2}$ Present address: South Side Senior High School, Rockville Centre, New York.

\section{Increase of Serum Globulin Levels with Age in Lake Whitefish, Coregonus clupeaformis ${ }^{1}$}

\section{INTRODUCTION}

Before the serum proteins in fishes can be used for phylogenetic and management studies, a knowledge of the manner in which these proteins may vary is needed. I have reviewed (Booke, 1964a) studies which have shown that sex, spawning, food, osmotic pressure, disease, temperature, light, age, hibernation, hormones, oxygen depletion, and season are factors which have an effect on the total serum protein complement of fish. The purpose of this study is to examine the variability of the blood-serum protein components in lake whitefish by age-groups.

\section{MATERIALS AND METHODS}

A group of whitefish in Munising Bay (Michigan), Lake Superior was chosen for study. The fish were caught in commercial pound nets. The blood samples were taken from unanesthetized fish as they were removed from the pound nets on 19-20 July 1961 between 6 AM and 10 AM. Approxi-

${ }^{1}$ Derived from a M.S. thesis submitted to the Dept. of Zoology, Michigan State Univ., 1962, 31 p. mately 1 to 2 cc of blood were removed from each fish by cardiac puncture with 20 -gauge hypodermic needles plus syringes and placed in centrifuge tubes to clot. Clotting occurred within approximately 1 minute. The sexes were not separated. The blood samples were centrifuged for 15 minutes at $3,500 \mathrm{rpm}$ to separate the serum from the clotted cells. The serum samples were frozen and later transported to the laboratory under dry-ice protection from thawing. All of the samples were analyzed within a period of 5 to 12 days after collection.

The 52 fish sampled ranged in age from 3 to 9 years. Their size and weight varied from 24 to $47 \mathrm{~cm}$ and 199 to $1,619 \mathrm{gm}$. The age of the fish was determined from scale annuli.

The analytical work was conducted on the Spinco-Beckman Model-R paper electrophoresis system. Procedure (B), Spinco Technical Bulletin TB-6050A ${ }^{2}$ was used with the exception that all separations of 10 -microliter samples were made at a constant current of 5 milliamperes per cell during a period of 16 hours at room temperature $(24 \pm 2 \mathrm{C})$. The dyed paper strips were analyzed by the Spinco Analytrol (Model RB), which translates the protein components on the strips into a pendrawn curve (analytrol sheet), with the height of the curve being in direct proportion to the protein-dye density at any given point on the paper strips. This apparatus provides an automatic integration of the area subtended by this curve, thus allowing calculation of relative protein densities for any portion of the profile.

Under these existing standardized conditions, identical proteins will occur at the same location on the paper strips and differences among paper strips must be interpreted as resulting from the presence or absence of different proteins or from differences in concentrations of the same proteins. Sixteen 10 microliter applications from one individual fish serum sample were placed on paper strips and analyzed. The results indicated that approximately a $3 \%$ error in reproducibility could be expected for the protein components separated.

\footnotetext{
${ }^{2}$ Beckman/Spinco, Inc., Palo Alto, California.
} 
TABLE 1.-Relative concentrations of serum proteins from whitefish of different ages

\begin{tabular}{|c|c|c|c|c|c|c|c|}
\hline & & \multirow{2}{*}{$\begin{array}{l}\text { Number } \\
\text { of tish }\end{array}$} & \multicolumn{5}{|c|}{ Component } \\
\hline & & & 1 & 2 & 3 & 4 & 5 \\
\hline \multirow[t]{4}{*}{ Agc-group } & III & 4 & $18.5 \pm 0.3^{1}$ & $22.8 \pm 0.1$ & $18.2 \pm 0.3$ & $21.4 \pm 0.3$ & $14.2 \pm 0.0$ \\
\hline & IV & 30 & $22.3 \pm 0.6$ & $20.0 \pm 0.2$ & $19.0 \pm 0.4$ & $20.9 \pm 0.6$ & $12.9 \pm 0.6$ \\
\hline & V & 16 & $25.5 \pm 0.5$ & $20.2 \pm 0.1$ & $15.5 \pm 0.2$ & $20.2 \pm 0.4$ & $12.7 \pm 0.4$ \\
\hline & IX & 2 & $31.6 \pm 0.0$ & $16.7 \pm 0.1$ & $20.0 \pm 0.1$ & $19.3 \pm 0.4$ & $9.2=0.6$ \\
\hline
\end{tabular}

'All values represent sample means and standard deviations in per cent units.

Each protein component was given a number starting with number one for the slowest moving component to number five, the fastest moving component. The percentage composition for each protein component which separated was calculated from the data on the analytrol sheets. For comparative purposes the percentage data was transformed using the arcsin method suggested by Snedecor (1956). There were enough fish sampled in age-groups III, IV, V, and IX to allow for comparison of similar protein components in these age-groups. An analysis of variance on a one-way classification was done to determine if there was a significant difference among age-groups for percentage composition of each protein component separated.

\section{RESULTS AND DISCUSSION}

The mode of the electrophoretic patterns and the number of serum protein components separated remained the same for all of the age-groups that were sampled. The percentage composition of components one and three showed a significant difference among agegroups at the $95 \%$ confidence level. These components were the slower moving ones and would be in the globulin portion of the serum if compared with human sera protein patterns. There were no significant differences in percentage composition of components two, four, and five among age-groups.

Serum globulin component one increased with age (Table 1 ). This increase may be related to raises in globulin antibody production as the fish is exposed to various diseases during life or it may be a normal development as the fish matures. Similar results have been obtained for globulins in mammals (Moore et al., 1945), in birds (Brandt et al., 1951), and in coho salmon (Vanstone and Ho, 1961).

Component three increased with age but showed a decrease at age $\mathrm{V}$ for which no apparent reason could be found (Table 1). This protein component is also a globulin and the physiological stage of the fish at age $V$ may require an increased use of this component accompanied by a slow replacement. It is possible that the number of fish sampled for this age-group may not have been large enough to provide an unbiased evaluation of this component's concentration.

I (1964b) have found no difference between total serum protein levels for male and female brook trout except during the spawning period. The whitefish sampled in the present study were not in spawning condition. If the serum protein levels of these fish have a similar seasonal pattern as found in brook trout, it would be likely that the increases described for components one and three were age-associated rather than due to the sexual makeup of the sample.

\section{LITERATURE CITED}

Booke, Henry E. 1964a. A review of variations found in fish serum proteins. New York Fish Game J. 11: 47-57.

- 1964h. Blood serum protein and calcium levels in yearling Brook trout. Progr. Fish-Cult. 26: $107-110$.

Brandt, L. W., R. E. Clegc, and A. C. Andrews. 1951. The effect of age and degree of maturity on the serum proteins of the chicken. J. Biol. Chem. 191: 105-111.

Moore, D. H., S. Shen, and C. Alexander. 1945. The plasma of developing chick and pig em. bryos. Proc. Soc. Exp. Biol. Med. 58: 307-310.

SNEDkCoR, G. 1956. Statistical Methods. 5th edition. Iowa State College Press, Ames, Iowa, $534 \mathrm{p}$.

Vanstone, W., and F. Chung-Wai-Ho. 1961. Plasma proteins of Coho salmon, Oncorhynchus kisutch, as separated by zone electrophoresis. J. Fish. Res. Bd. Canada 18: 393-399.

Henry E. Booke

Museum of Zoology-Fish Division

University of Michigan

Ann Arbor 